\title{
The role of hepatitis $C$ virus genotyping in evaluating the efficacy of INF-based therapy used in treating hepatitis $C$ infected patients in Libya
}

\author{
Mohamed A Daw ${ }^{1 *}$, Hana A Elasifer ${ }^{1}$, Aghnaya A Dau² and Mohamed Agnan ${ }^{3}$ \\ *Correspondence: mohamedadaw@gmail.com \\ 'Department of Medical Microbiology \& Immunology, Faculty of Medicine, Tripoli - Libya. \\ ${ }^{2}$ Department of Surgery, Faculty of Medicine Tripoli - Libya. \\ ${ }^{3}$ Department of Pharmacology, Faculty of Medical Technology, Alga-bal Algarbi University, Libya.
}

\begin{abstract}
Background: Hepatitis $\mathrm{C}$ virus (HCV) therapy has been evolved over years and many parameters were used to evaluate such therapy particularly genotyping. In North Africa and Eastern Mediterranean the genotypes vary from most of world and rarely studies were conducted to assess the influence of such genotypes on the HCV therapy.

Aims: This study was designed to determine; the role of HCV genotyping in assessing the efficacy of interferon therapy and to analyze the rates of sustained virological response (SVR) in INF and PegIFN-based regimens according on HCV genotype infecting Libyan patients with chronic hepatitis C infection.

Methods: A total of 479 patients with chronic HCV registered at Tripoli Medical Centre were treated with 'INF alfa or PEGINF- Pegylated INF alfa $2 \mathrm{a}$ in combination with ribavirin' for a five year period. These patients were registered and followed up from January 2007 to October 2012. The information were reviewed and data were collected from each patient regarding age, gender, ALT level, and viral load, viral genotype using qualitative PCR. The statistical analysis were carried using SPSS version 11.5 .

Results: Of the patients studied 86 patients were treated with INF based regimen, only $54 \%$ of them had end treatment response (ETR) and 28\% had SVR. Off 143 patients treated with peg-INF alfa 2a based therapy; 69\% had ETR and 36\% had SVR. The SVR of Peg-INF based regimen was higher than INF based regimen in all genotypes except for genotype 4 . The relationship between SVR and gender was significant in patients who were given INF based therapy comparable to PEG INF based regimen, though the relationship between SVR and age, basal viral load and basal ALT were also reported in both regimens.

Conclusions: HCV genotyping has been found to play an important valuable role in determining the efficacy of Hepatitis C therapy. SVR vary according to the HCV genotype involved. HCV genotype 1 and 4 were found to be the prevalent resistant genotypes infecting Libyan patients. Such findings are particularly important in guiding the clinical therapy of patients infected with hepatitis $\mathrm{C}$ virus.
\end{abstract}

Keywords: Hepatitis C virus, interferon, Libyan patients, HCV genotypes

\section{Introduction}

Hepatitis C virus (HCV) has been considered to be one of the most ongoing causes of viral hepatitis. Deaths due this virus are expected to be tripled in next 20 years, particularly among developing countries [1]. This imposes a major personal and social burdens on infected individual further to a heavy economic hurdles on health and insurance sectors [2]. Hence then having proper valuable therapy, easily monitored will be priority for clinicians and researchers involved in the management of HCV infection.

Treatment of Hepatitis of $C$ infection has been evolved over years and many regimens has been introduced $[3,4]$. The early used drug was interferon (INF) alpha; the addition of a polyethylene glycol (Peg) moiety to INF (termed, Peg-INF) has dramatically enhances its span life in blood and thus it reduces the needed dose $[\mathbf{5 , 6 ]}$. This efficiency was significantly improved with the addition of guanosine analogue ribavirin
(RBV). Combination therapy particularly (Peg-INF) with RBV has been considered to be effective therapies for chronic HCV $[7,8]$. Such therapy was not well tolerated with all patients. Hence then more effective and tolerable treatments were introduced among them, direct-acting antiviral (DAA) drugs such as telaprevir, and boceprevir, which were approved for clinical use recently $[9,10]$. These could be used in combination with pegylated interferon and ribavirin particularly in treatment-na"ive and problematic patients [11]. Despite the increasing advancement in such therapy and the ultimate increase in the clearance rate which reached up to $80 \%$ in different clinical trials, emergence of resistant viral variants has been reported [12]. Hence then, therapy of HC Infection should be effectively monitored and different parameters were introduced to assess its efficacy. Both host and viral factors were found to be associated with such treatment particularly with non-response to PEG-INF. Viral factors include viral load, genotype and quasi-species of 
Daw et al. Virology Discovery 2013,

HCV. Each patient should be anticipated to follow a specific criterion that might include, progress of disease, predisposing factors, symptomology and viral status $[13,14]$.

Hepatitis C Genotyping plays an important role in the clinico-epidemiological manifestations of $\mathrm{HC}$ infection and the existence of six major types virus genotypes and about 100 subtypes, which, have been identified with distinct geographic distributions. Genotypes 1, 2 \& 3 accounted for the majority of HCV infections worldwide [15]. Genotype-1, the most common genotype, it is dominant in USA, Europe and most Asia-Pacific [16]. Genotype-2 in Japan, South Korea and southern Taiwan $[17,18]$. Genotype-3 is prevalent on the Indian subcontinent and Australia. Genotype- 4 is predominantly found in the Middle East and North Africa [2] though genotype -5 was limited to South Africa [19], and HCV-6-11 was found in South-East Asia [20]. Such variation starts to change due worldwide massive social surge and cultural diversity.

HCV genotype is the strongest baseline predictor of IFN response and the efficacy of $\mathrm{HC}$ therapy has been influenced by HCV genotypes and different genotypes showed different clinical responses to HCV therapy. Hence then, the use of HCV genotyping in assessing the therapy of Hepatitis $\mathrm{C}$ infection is becoming valuable important aspect $[\mathbf{9 , 2 1}$. Monitoring of $\mathrm{HCV}$ drug resistance before and during treatment is likely to provide important information for management of patients undergoing anti-HCV therapy. The objectives of this study were to evaluate the efficacy of IFN and peg-INF-based regimens and determine factors that influence the response and resistance of the regimens used and the role of HCV genotyping in predicting on monitoring the response of such therapy.

\section{Patients and methods Patients population}

A total of 479 patients with hepatitis $C$ virus were studied. The patients were recruited from the Department of Infectious Diseases at Tripoli Medical Centre, Tripoli. All were registered and followed up at Out Patient Department from January 2007 to October 2012. Three hundred and three patients were male and 176 patients were female. (Male; Female ratio 1.7:1). The age was ranged from 16 to 84 years with an average age of 40 years at the entry of the study.

The data collected was designed to extract information from patients that may influence the outcome of viral therapy such as age, gender and year of diagnosis of HCV. The participation was voluntary in accordance of with the guidelines for observational and interventional studies of national ethical committees as the research was conducted according to Helsinki Declaration [22] and Libyan National committee for ethical approval number LETC/THCV-T77/2006.

\section{Patient exclusion criterion}

Each patient has to fulfil the specific criteria that include; no co infection with human immune-deficiency syndrome
(AIDS) virus or with hepatitis B virus and HDV, and none of them had liver cirrhosis, or undergo haemodialysis; and no concomitant metabolic or autoimmune disorder or underlying systemic diseases.

\section{Study design}

This randomised clinical study was conducted at Tripoli Medical Centre as patients were randomly assigned. Antiviral therapy was administrated to 229 patients, 86 patients were given INF-alfa plus Ribavirin combination therapy and 143 were given pegylated interferon-alfa 2a plus Ribavirin combination therapy. The INF alfa dose were 3 million IU subcutaneously three times a week for 24 weeks for genotypes ( 2 and 3 ) and for 48 weeks for genotypes ( 1 and 4). The Peg INF-alfa 2a was given as fixed dose of 180 microgram once a week for 24 weeks for genotypes ( 2 and 3 ) and for 48 weeks for genotypes ( 1 and 4). Ribavirin was given as $800 \mathrm{mg}$ daily dose, 200-mg capsules twice a day in combination with INF or Peg INF for 24 weeks for genotypes ( 2 and 3 ) but for genotypes (1 and 4) the full daily dose was adjusting according to body weight $1.000 \mathrm{mg}$ daily dose for patients weighted $75 \mathrm{~kg}$ or less and 1.200 daily dose if patients weighted more than 75 $\mathrm{kg}$ the dose was given twice a day in combination with INF or Peg-INF for 48 weeks. End treatment response (ETR) was defined as undetectable HCV RNA at the end of treatment which takes at least 12 weeks. Sustained virological response (SVR) was defined as undetectable HCV RNA at 24 weeks after completion of treatment.

\section{Laboratory and Clinical Evaluation of HCV Infection Virological Studies}

A serum specimen was collected from each patient and was tested positive for $\mathrm{HCV}$ antibody (Anti-HCV) using and $3^{\text {rd }}$ generation commercial Enzyme Linked Immunosorbant Assays (ELISA) The INNO-LIA ${ }^{\mathrm{TM}} \mathrm{HCV}$ Ab III update is $3^{\text {rd }}$ generation line immunoassay which incorporates $\mathrm{HCV}$ antigens derived from the core region, the E2 hyper-variable region, the NS3 helicase region, the NS4A, and NS5A regions. The antigens were coated on a nylon strip with plastic backing as 6 discrete lines. Then, in each strip every four control lines were coated: strepavidin control, 3+Positive Control (antihuman Ig), 1+Positive Control (human IgG) and+cut-off line (human IgG). Incubated with test sample then purified alkaline phosphatase was added-labelled goat anti-human IgG and lastly we added conjugate [1].

\section{Determination of HCV genotypes}

The genotyping in this study was carried out by gene amplification using COBAS-Amblicor HCV test as early described [1], detected by reverse-transcribing HCV RNA into CDNA by PC, hybridizing amplified CDNA with an oligonucleotid probe that binds enzyme, and catalyzing conversion of substrate to a colored product that is recognized by COBAS AMBLICOR Analyzer (Roche, Diagnostic, Basal, Switzerland). 
Daw et al. Virology Discovery 2013,

Table 1. Base line clinical characteristics of patients enrolled for the study.

\begin{tabular}{ll}
\hline Clinical Characteristics & Number of Patients(\%) \\
\hline Patients population & \\
Total patients involved & $479(100)$ \\
Male & $303(63.3)$ \\
Female & $176(36.8)$ \\
Age in years & $16-86$ \\
\hline Patients disposition & \\
Refused treatment & $149(31.10)$ \\
Involved in the treatment & $372(77.7)$ \\
Finished Treatment & $229(47.8)$ \\
Discontinued treatment & $143(29.9)$ \\
\hline Virologica response & \\
Response to Inf based regimen & $70(14.6)$ \\
Response to Peg Inf based regimen & $149(30.9)$ \\
\hline Monitoring viral response & \\
Alanine aminotransferase, & $219(45.7)$ \\
IU/L HCV-RNA level & \\
$<$ 200,000 IU/ml & $130(27.1)$ \\
$>$ 200,000 IU/ml & $89(18.6)$ \\
\hline
\end{tabular}

\section{Determination of viral load}

HCV load was performed by COBAS ${ }^{\mathrm{R}}$ TaqMan $^{\mathrm{R}} \mathrm{HCV}^{\mathrm{T}}$ Test, v2.0 which based on three major processes [1] manual specimen preparation to extract HCV RNA, [2] automated reverse transcription of the target RNA to generation complementary DNA, [3] PCR amplification of target CDNA using HCV specific complementary primers and simultaneous detection of cleaved dual fluorescent dye- labelled oligonucleotide probes. The Master Mix reagent contains primer pairs and probes specific for both HCV RNA and HCV Quantitation Standard RNA as previously published [1]. The detection of amplified using target specific and Quantitation Standard specific dual labelled oligonucliotide probes that permit independent identification of HCV amplicon and HCV Quantitation Standard amplicon, and also quantitation of HCV viral RNA is performed using the HCV Quantitation Standard. The test has limits of detection approximately $50 \mathrm{IU}$ per $\mathrm{ml}$, (Roche, Diagnostic, Basal, Switzerland). Biochemical parameters such as ALT (alanine aminotransferase) (GPT) and AST (aspartate aminotransferase) (GOT) were also analysed and evaluated for each patients.

\section{Statistical analysis}

Quantitative variables were expressed as mean \pm standard deviation and were compared by Student's test (t-test). Differences in proportion of qualitative variables were tested with non-parametric tests $(\mathrm{X} 2)$ Yates correlation. Fisher exact test and a $p$ value $<0.05$ were considered significant. A multivariate analysis was conducted using logistic regression in order to verify which variables statistically had an influence on HCV infection. such as gender (male vs. female), IV drug abuser (yes or no), blood transfusion (yes or no) surgical Intervention (yes or no), dental care (yes or no); Heterosexuality and homosexuality (yes or no). The calculation of $95 \%$ Confidence Interval (Cl) to compare groups was determined and the data were analyzed using SPSS version 11.5 to evaluate the efficacy of therapy and its association with genotypes, gender, ALT, viral load, and also to assess the sustained virological response (SVR) in different genotype, and finally the different regimens of therapy efficacy were compared.

\section{Results}

\section{Efficacy of HCV therapeutic regimens}

Initially 479 patients with chronic HCV were recruited to be included in this study their clinical characteristics were shown in Table 1. Off 107 (22.3\%) patients of them were withdrawn from the study, as they refused to take the drugs or unwilling to participate in the study and thus they were failed to meet the inclusion criteria. A total of $372(77.7 \%)$ patients who fulfilled the criteria were enrolled in the study, 143 (38.4\%) of them did not finish the study and 229 (61.6\%) patients finished the treatments of both regimens. Off 229 patients who finished the treatment, 86 of them were given INF-alfa plus ribavirin combination therapy and 143 were given Pegylated INF-alfa 2a plus ribavirin combination therapy.

Regarding the first regimen, a total of 86 patients who were given INF based treatment, forty six (54\%) of them had end treatment response (ETR), and $22(26 \%)$ of patients who had ETR relapsed. Though, 24 (28\%) patients who received this regimen showed sustained virological response (SVR). Fifty patients who were given INF alfa based therapy were males, 21 (42\%) of them had ETR. Thirty six patients who were given INF alfa based combination therapy were females, and 25 (69.4\%) of them had ETR. The relationship between ETR to INF based therapy and gender was statistically significant $\mathrm{Cl}=(1.5-3.5),(P=0.009)$. According to gender, only $10(20 \%)$ male patients $(n=50)$ had SVR, and $14(38.9 \%)$ female patients $(n=36)$ had SVR. The relationship between gender and SVR was statistically significant $\mathrm{Cl}=(0.9-2.5)(P=0.016)$.

Regarding the second regimen, 98 (69\%) of patients who were given PEG INF alfa 2a based therapy showed ETR, 47 (33\%) of them relapsed. Though of this regimen 51 (36\%) patients had SVR. A total of 88 patients who were given Peg INF alfa based combination therapy were males, 57 (68.8\%) of them had ETR. Though 55 patients who were given Peg INF alfa based combination therapy were females, and 41 (74.5\%) of them had ETR. SVR was also analyzed, accordingly 28 (31.8\% $\mathrm{n}=88)$ male patients had SVR, and $23(41.8 \% \mathrm{n}=55)$ female patients had SVR Cl=(0.5-1.2) $(P=0.268)$.

The ETR and SVR of both regimens was determined according to different age group as shown in Table 2. A younger age patients were found to be responding better for both regimens used though Peg INF was more superior 
Daw et al. Virology Discovery 2013,

http://www.hoajonline.com/journals/pdf/2052-6202-1-3.pdf

doi: $10.7243 / 2052-6202-1-3$

Table 2. The distribution of responders and non-responders to both therapeutic regimens according the age group among chronic $\mathrm{HCV}$ infected patients.

\begin{tabular}{c|cccccccc}
\hline \multirow{2}{*}{ Age group } & \multicolumn{4}{|c}{ Responders(\%) } & \multicolumn{4}{c}{ Non-responders(\%) } \\
\cline { 2 - 9 } & \multicolumn{2}{|c}{ INF } & \multicolumn{2}{c}{ PEG INF } & \multicolumn{2}{c}{ INF } & \multicolumn{2}{c}{ PEG INF } \\
\cline { 2 - 9 } & ETR & SVR & ETR & SVR & ETR & SVR & ETR & SVR \\
\hline $15-34$ & 15 & 8 & 42 & 26 & 14 & 21 & 15 & 31 \\
$35-44$ & 16 & 8 & 29 & 17 & 11 & 19 & 18 & 30 \\
$45-54$ & 9 & 6 & 17 & 4 & 6 & 9 & 6 & 19 \\
$55-84$ & 6 & 2 & 10 & 4 & 9 & 13 & 6 & 12 \\
Total & $46(56.7)$ & $24(34.3)$ & $98(65.8)$ & $51(34.2)$ & $40(39.2)$ & $62(60.8)$ & $45(32.8)$ & $92(67.2)$ \\
\hline
\end{tabular}

ETR; end treatment response, SVR; sustained virological response.

in $\mathrm{ETR} \& \mathrm{VSR} C \mathrm{Cl}=(3-4.3) ; \mathrm{Cl}=(0.4-2.0)(P=0.626 ; P=0.105)$.

\section{Monitoring of therapeutic regimens}

Both liver function tests and viral load were monitored in this study, off 26 patients on INF based therapy who had ETR had normal ALT and 20 of them had raised abnormal ALT at diagnosis. Though, 14 patients who had SVR had normal ALT level at diagnosis where as 10 patient who had SVR had abnormal ALT level at diagnosis. In PEG INF based group Where 57 patients who had ETR had normal ALT and 41 of them had elevated ALT. Furthermore, 25 patients of them who had SVR had normal ALT level at diagnosis where as 26 patients who had SVR had abnormal ALT level at diagnosis. The analysis of viral load showed that, in the first group based regimen 24 of patients who had ETR had low viremia at diagnosis (viral load less than 2 million and 22 of them had abnormal high viremia(viral load higher than 2 million) at diagnosis. While 12 patients who had SVR had low viremia at diagnosis at diagnosis where as 12 patient who had SVR had high viremia at diagnosis. In the second group 61 of patients who had (PEG INF based therapy) ETR had low viremia and 37of them had high viremia, While 33 patients who had SVR had low viremia at diagnosis where as 18 patients who had SVR had high viremia at diagnosis.

\section{Role of HCV genotyping in monitoring therapy}

The ETR and SVR of both regimens were correlated with the different HCV genotypes of the studied patients as shown in Table 3. Accordingly, different genotypes were reported among the patients. Those who received the first regimen(INF based therapy); 24 patients shown genotype $1 ; 33.3 \%$ of them had end treatment response (ETR), 13 patients with genotype 2; $69.2 \%$ had ETR, 21 patients with genotype 3; 52.4\% had ETR, 28 of patients with genotype $4 ; 64.3 \%$ had ETR. On intention to treat 143 patients with the second regimen who were given Peg INF alfa2a based combination therapy. Off them 128 patients completed the course of treatment, 56 patients with genotype $1 ; 66.1 \%$ had ETR, 17 patients with genotype 2; $82.4 \%$ had ETR, 16 patients with genotype $3 ; 68.8 \%$ had ETR, 54 patients infected with genotype $4 ; 66.7 \%$ of them had ETR.
Sustained virological response to INF alfa was measured by qualitative PCR after six months of end of the course of treatment only to responder, the end treatment response were recorded in 46 patients 24 of them the HCV RNA was undetected and 9 patients the HCV RNA were detected and 13 of responders were unknown 'patients missed the follow up', so 22 patients about $46.7 \%$ from responder did not have sustained virological response 'relapsed'. But on intention to treat about $27.9 \%$ had SVR and 62 patients about $72.1 \%$ did not had SVR. In patients who were given Peg INF combination therapy 98 of them had ETR; 51 of them had SVR, on intention to treat about $35.7 \%$ of patients had SVR. Ten of who had ETR had detected HCV RNA after six months about and 37 patients did not do PCR after six months, so about $48 \%$ of patients who had ETR relapsed.

Table 3. shows the correlation between SVR of both regimens and the different genotypes of HCV. Accordingly on intention to treat (INF based therapy) about $16.7 \%$ of genotype $1, \mathrm{HCV}$ infected patients had SVR, 30.8\% of genotype 2 infected patients had SVR, $23.8 \%$ of genotype 3 patients had SVR and $39.3 \%$ genotype 4 infected patients had SVR. In the second group and according to genotypes on intention to treat (PEG INF based therapy) genotype 1 infected patients about 32.1\% had SVR and genotype 2 infected patients $35.3 \%$ had SVR, and about $43.7 \%$ of genotype 3 infected patients had SVR where as $37 \%$ of genotype 4 infected patients had SVR. Figure 1 Illustrates the correlation between Viral response rates of different HCV genotypes and both End of Treatment Response (ETR) and sustained Virologic Response (SVR), according to intention -to -treat analysis.

\section{Discussion}

Hepatitis $\mathrm{C}$ virus infection results in chronic active hepatitis in more than $80 \%$ of infected patients; 20 to $30 \%$ of these patients develop progressive fibrosis and cirrhosis, whereas only approximately 10 to $20 \%$ of the infected people spontaneously eliminate the virus [23]. Treatment regimens for chronic hepatitis $C$ have significantly improved during the last decade, resulting in higher sustained virological response (SVR) rates [24]. The dual anti-HCV therapy is based on administration 


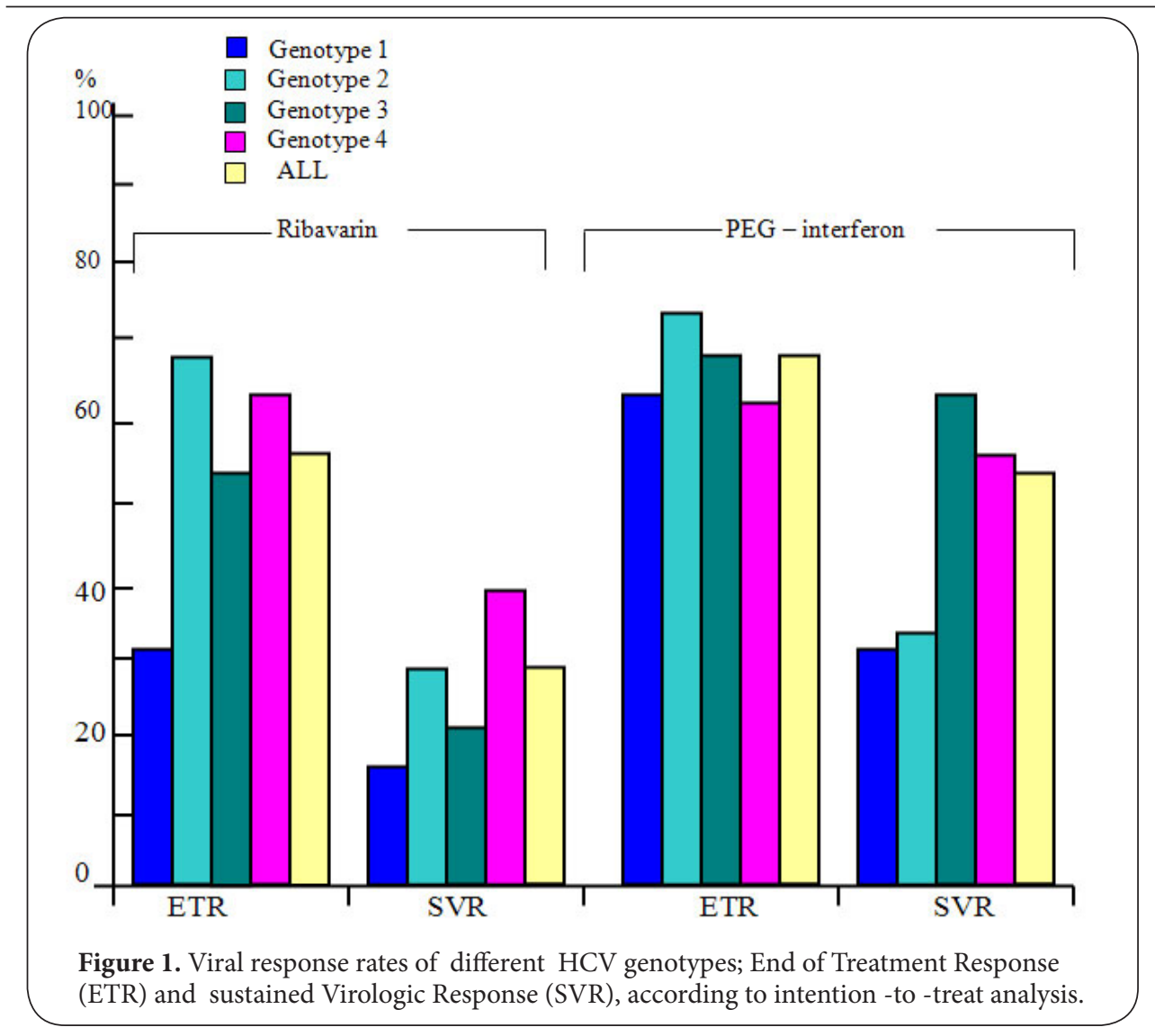

Table 3. The influence of HCV genotyping on the outcome response of both regimens studied.

\begin{tabular}{|c|c|c|c|c|c|c|c|c|}
\hline \multirow{3}{*}{$\begin{array}{r}\text { Genotype/ } \\
\text { subtype }\end{array}$} & \multicolumn{4}{|c|}{ Responders(\%) } & \multicolumn{4}{|c|}{ Non-responders(\%) } \\
\hline & \multicolumn{2}{|c|}{ INF } & \multicolumn{2}{|c|}{ PEG INF } & \multicolumn{2}{|c|}{ INF } & \multicolumn{2}{|c|}{ PEG INF } \\
\hline & ETR & SVR & ETR & SVR & ETR & SVR & ETR & SVR \\
\hline Genotype 1a & 0 & 0 & 9 & 5 & 3 & 3 & 2 & 6 \\
\hline $1 b$ & 3 & 1 & 14 & 7 & 7 & 9 & 13 & 20 \\
\hline $1 \mathrm{UC}^{*}$ & 5 & 3 & 14 & 6 & 6 & 8 & 4 & 12 \\
\hline Genotype 2a & 0 & 0 & 1 & 1 & 1 & 1 & 0 & 0 \\
\hline $2 b$ & 0 & 0 & 1 & 0 & 0 & 0 & 0 & 1 \\
\hline $2 c$ & 0 & 0 & 2 & 0 & 0 & 0 & 0 & 2 \\
\hline $2 \mathrm{a} / \mathrm{c}$ & 0 & 0 & 0 & 0 & 1 & 1 & 1 & 1 \\
\hline $2 \mathrm{UC}$ & 9 & 4 & 10 & 5 & 2 & 7 & 2 & 7 \\
\hline Genotype $3 a$ & 2 & 1 & 1 & 1 & 0 & 1 & 1 & 1 \\
\hline $3 \mathrm{UC}$ & 9 & 4 & 10 & 6 & 10 & 15 & 4 & 8 \\
\hline Genotype 4a & 4 & 3 & 4 & 1 & 2 & 3 & 4 & 7 \\
\hline $4 \mathrm{c} / \mathrm{d}$ & 0 & 0 & 4 & 3 & 1 & 1 & 3 & 4 \\
\hline $4 \mathrm{UC}$ & 14 & 8 & 28 & 16 & 7 & 13 & 11 & 23 \\
\hline Total & $46(65.7)$ & $24(34.3)$ & $98(65.8)$ & $51(34.2)$ & $40(39.2)$ & $62(60.7)$ & $45(61.7)$ & $92(67.2)$ \\
\hline
\end{tabular}

${ }^{\star} \mathrm{UC}$; Unclassified, ETR; End treatment response, SVR; sustained virologica response.

of long-acting pegylated alpha interferon (IFN) and ribavirin (RBV). Different factors have been evaluated as predictors of the sustained response to treatment, with controversial results [25]. In the present study we analyzed the efficiency of two regimens INF or PEG-INF alpha 2; either one was given in combination with RBV in treatment HCV infected patients. 
Daw et al. Virology Discovery 2013,

Off the patient treated with INF based regimen; $54 \%$ of them had ETR, 28\% showed SVR and $26 \%$ relapsed, compared with PEG-INF based therapy where $69 \%$ showed ETR, 36\% had SVR, and $33 \%$ who had ETR relapsed. This showed that PegINF has a better clinical outcomes compared to INF based regimen among Libyan patients infected $\mathrm{HC}$ Virus. Our data are in concordance with other studies that used the same regimens [26]. Discontinuation of HCV antiviral treatment was reported in both regimens used, it was 15 patients in Peg-INF and 10 patients in INF based regimen. Studies on HCV infected patients of Caucasian and African Americans had shown $21 \%$ a discontinuation rate, though in Japanese patients different rates were reported vary from $10.3 \%$ to $21 \%$ [27]. This is consistent with our result, though we could not analyze the effect on SVR of discontinuing in certain patients. Despite no specific correlation could be made between these studies, it's obvious that the tolerability of antiviral regimens used was satisfactory.

Different factors have been known to predict clinical response of antiviral-therapy among $\mathrm{CHV}$ patients these may include patient, viral and biochemical parameters $[\mathbf{2 8 , 2 9 ]}$. Patient associated factors such as gender, age and the ethnic clan, have been studied by many investigators $[2,30]$. In this study we found a significant relationship between gender and both ETR and SVR in INF based therapy. Female patients had a higher SVR than male patients and the relationship was insignificant in PEG INF based therapy. Such results are compatible with other studies that revealed male sex had worse prognosis to therapy than female, that is may be because male patients have more ability to have liver cirrhosis [25].

The relationship between age groups and SVR were assessed in this study. A younger patients less than 40 years of age, were found to have a higher SVR rate compared with the older ones. This however, is an agreement with other studies, who reported that SVR rate in older patients was remarkably low at $17.4 \%$ compared to SVR rate in all patients included in study which was $36.0 \%$ these results were in disagreement with other studies carried in Pakistan where a significant relationship between age group and SVR as they found younger patients had higher SVR [31,32].

In this study we evaluated the biochemical parameters that have their influence on the SVR of both regimens used. Its well documented that most patients with an SVR normalize their serum ALT, AST shortly after discontinuing treatment unless other liver disease is present. The relationship between ALT and viral load level at diagnosis were insignificant in both regimens, some studies found inverse relationship between basal viral load and response to therapy [29]. Others did not found such relationship [33]. High ALT levels are correlates with liver cirrhosis but some studies revealed no relationship between response to therapy and ALT level before treatment $[5,32]$. This however is not the case of our study as those with live cirrhosis did not fit with patient selection criterion we applied.
Different viral related factors have been found to be involved in response of interferon treatment. Viral genotype, genetic diversity, viral load and kinetics where found to be among the most important ones involved. Recently, our group [34] and others $[35,36]$ reported different rates of infection with different virus genotypes which was reflected on the viral response to the therapy used in treating $\mathrm{HC}$ infection. Interestingly, several studies have demonstrated that the chance to respond to IFN treatment is related to the baseline viral load. In this study strong association was found between viral load and ETR of patients treated INF based compared with those treated with Peg INF alfa2a therapy $(P=0.976)$. Patients with a high viral load are less sensitive to the treatment than patients with a low viral load. Thus, patients with genotypes, low baseline viral load and RVR may be treated for a short period (eg., 24 weeks), while patients with genotypes, high baseline viral load and without RVR may require longer period (eg., 48 weeks) of treatment.

In this study according to genotypes and on intention to treat, ETR of patients treated PEG INF alfa 2a based regimen were superior to INF alfa based regimen in all genotypes though it was particularly significant in HCV genotype 1 (' $P$ value $\left.=0.025^{\prime}\right)$. These results were in agreement with the studies carried at University of Southampton [37]. Further more in both regimens HCV genotype 2, had a higher ETR than genotype 1 and 4 which same as previous study was carried in Cameroon [38]. However, both therapeutic regimens were less effective in patients infected with HCV genotype 1 and 4 although much higher ETR rates are reached in individuals infected with genotype 2 .

Other studies have shown no differences in the clinical response of patients infected with HCV genotype 2 and 3 , when they were treated with PEG INF alfa2a or INF alfa combination therapies $[38,39]$. The SVR of Peg INF based regimen was higher than INF based Regimen in all genotypes except for genotype 4 because as 11 patient infected with this genotype had ETR of Peg INF miss the follow up and thus excluded for the data analysis. Though, for those patients treated with INF based regimen, SVR was higher among patients infected with genotype 4 comparable to genotype 2 and 3 this may be related to discontinuation of therapy among the patients. The SVR in genotype 1 infected patients was the least in both regimens comparable to other genotypes. These results are similar to other studies carried in France on selected multiethnic patients from France, Egypt and other African countries who were treated with Peg INF alfa 2a based regimen $[26,39]$. In their study the selected patients were French and Egyptian and other African who had HCV genotype 4 infection on Peg INF alfa 2a they found. SVR was variable according to the ethnicity as it was $54 \%$ among Egyptian, $40.3 \%$ in French patient and among Africans it was $32.4 \%$ [40]. The relationship between HCV subtypes and ETR and SVR were also studied. No significant relationship was found, particularly with patients with HCV genotype $1 \mathrm{a}$ and $1 \mathrm{~b}$. 
Our studies are in accordance with those carried by Zeuzem; who did find heterogeneous virological response rates to interferon- based therapy in patients with chronic hepatitis $C$ based on genotypes and subtypes of HCV $[37,41]$. Hence then virus clearance rates are variable different depending on viral genotypes and that could be used to monitor HCV therapy.

Despite the limitations that this study facing due to the inability of some patients to finish the due course of the therapy and the discontinuation of the regimens among others. Our results highlights the importance of monitoring antiviral therapy and the factors that influence such therapy among treated patients.

In conclusion, we have found that Responsiveness to hepatitis $C$ virus therapy is variable according to the different regimens used. Certain factors such as gender, age, viral load and genotypes influence viral response rate. Furthermore, genotype 1 and 4 were more resistant comparable with other genotypes. Therefore, New drug therapies such as antiviral protease and antipolymerase should be combined with the ongoing therapy both to increase SVR among non responsive patients and reduce the duration of treatment particularly of those who were infected with resistant genotypes.

\section{Competing interests}

The authors declare no relationship (commercial or otherwise) that may constitute a dual or conflicting interest.

\section{Authors' contributions}

Daw MA; A leading expert in Microbial- epidemiology and Antimicrobial therapy, Designed the study, constructed the Manuscript and analyzed the data. HME; Followed the patients and collected the data. AAD; Analyzed the data \& read the MS. MMA; Assessed the clinical study, analyzed the data and read the MS.

\section{Acknowledgement}

The authors are grateful to all the members of Departments of Medical Microbiology Faculty of Medicine, and Infectious Diseases, Tripoli Medical Center for their help and assistant.

\section{Publication history}

Editor: Weifeng Shi, Guangzhou Institute

of Advanced Technology, China.

Received: 26-Mar-2013 Revised: 05-May-2013

Re-Revised: 12-May-2013 Accepted: 03-June-2013

Published: 18-Jun-2013

\section{References}

1. Daw MA and Dau AA: Hepatitis $C$ virus in Arab world: a state of concern. ScientificWorldJournal 2012, 2012:719494. | Article | PubMed Abstract | PubMed FullText

2. Daw MA, Dau AA and Agnan MM: Influence of healthcare-associated factors on the efficacy of hepatitis $C$ therapy. ScientificWorldJournal 2012, 2012:580216. | Article | PubMed Abstract | PubMed FullText

3. Alavian SM, Behnava B and Tabatabaei SV: Comparative efficacy and overall safety of different doses of consensus interferon for treatment of chronic HCV infection: a systematic review and meta-analysis. Eur J Clin Pharmacol 2010, 66:1071-9. | Article | PubMed

4. Marcellin $P$ and Asselah T: Treatment of viral hepatitis: a new era. Liver Int 2013, 33 Suppl 1:1-2. I Article I PubMed

5. Fried MW, Shiffman ML, Reddy KR, Smith C, Marinos G, Goncales FL Jr.,
Haussinger D, Diago M, Carosi G, Dhumeaux D, Craxi A, Lin A, Hoffman J and $Y u$ J: Peginterferon alfa-2a plus ribavirin for chronic hepatitis $C$ virus infection. N Eng/ J Med 2002, 347:975-82. | Article | PubMed

6. Kainuma M, Furusyo N, Kajiwara E, Takahashi K, Nomura H, Tanabe Y, Satoh T, Maruyama T, Nakamuta M, Kotoh K, Azuma K, Shimono J, Shimoda $S$ and Hayashi J: Pegylated interferon alpha-2b plus ribavirin for older patients with chronic hepatitis C. World J Gastroenterol 2010, 16:4400-9. | Article | PubMed Abstract | PubMed FullText

7. Witthoft T, Moller B, Wiedmann KH, Mauss S, Link R, Lohmeyer J, Lafrenz M, Gelbmann CM, Huppe D, Niederau C and Alshuth U: Safety, tolerability and efficacy of peginterferon alpha-2a and ribavirin in chronic hepatitis C in clinical practice: The German Open Safety Trial. J Viral Hepat 2007, 14:788-96. | Article | PubMed Abstract| PubMed FullText

8. Yu ML and Chuang WL: Treatment of chronic hepatitis $\mathrm{C}$ in Asia: when East meets West. J Gastroenterol Hepatol 2009, 24:336-45. | Article | PubMed

9. Asselah T, Estrabaud E, Bieche I, Lapalus M, De Muynck S, Vidaud M, Saadoun D, Soumelis V and Marcellin P: Hepatitis C: viral and host factors associated with non-response to pegylated interferon plus ribavirin. Liver Int 2010, 30:1259-69. | Article | PubMed Abstract | PubMed FullText

10. Marcellin P and Asselah T: Editorial: Towards the eradication of hepatitis C virus. Liver Int 2012, 32 Suppl 1:1. | Article | PubMed

11. Sulkowski MS, Asselah T, Lalezari J, Ferenci P, Fainboim H, Leggett $B$, Bessone F, Mauss S, Heo J, Datsenko Y, Stern JO, Kukolj G, Scherer J, Nehmiz G, Steinmann GG and Bocher WO: Faldaprevir combined with peginterferon alfa-2a and ribavirin in treatment-naive patients with chronic genotype-1 HCV: SILEN-C1 trial. Hepatology 2013. | Article | PubMed

12. Fonseca-Coronado S, Escobar-Gutierrez A, Ruiz-Tovar K, Cruz-Rivera MY, Rivera-Osorio P, Vazquez-Pichardo M, Carpio-Pedroza JC, Ruiz-Pacheco $J A$, Cazares F and Vaughan G: Specific detection of naturally occurring hepatitis $C$ virus mutants with resistance to telaprevir and boceprevir (protease inhibitors) among treatment-naive infected individuals. J Clin Microbiol 2012, 50:281-7. | Article | PubMed Abstract | PubMed FullText

13. Daw MA, Elkaber MA, Drah AM, Werfalli MM, Mihat AA and Siala IM: Prevalence of hepatitis $C$ virus antibodies among different populations of relative and attributable risk. Saudi Med J 2002, 23:1356-60. | PubMed

14. Aziz H, Gil ML, Waheed Y, Adeeb U, Raza A, Bilal I and Athar MA: Evaluation of prognostic factors for Peg Interferon alfa-2b plus ribavirin treatment on HCV infected patients in Pakistan. Infect Genet Evol 2011, 11:640-5. | Article | PubMed

15. Mohd Hanafiah K, Groeger J, Flaxman AD and Wiersma ST: Global epidemiology of hepatitis $C$ virus infection: new estimates of agespecific antibody to HCV seroprevalence. Hepatology 2013, 57:1333-42. | Article | PubMed

16. Ward JW: The epidemiology of chronic hepatitis $C$ and one-time hepatitis C virus testing of persons born during 1945 to 1965 in the United States. Clin Liver Dis 2013, 17:1-11. | Article | PubMed

17. Aziz H, Raza A, Murtaza S, Waheed Y, Khalid A, Irfan J, Samra Z and Athar MA: Molecular epidemiology of hepatitis $C$ virus genotypes in different geographical regions of Punjab Province in Pakistan and a phylogenetic analysis. Int J Infect Dis 2013, 17:e247-53. | Article | PubMed

18. Sievert W, Altraif I, Razavi HA, Abdo A, Ahmed EA, Alomair A, Amarapurkar D, Chen CH, Dou X, El Khayat H, Elshazly M, Esmat G, Guan R, Han KH, Koike K, Largen A, McCaughan G, Mogawer S, Monis A, Nawaz A, Piratvisuth T, Sanai FM, Sharara Al, Sibbel S, Sood A, Suh DJ, Wallace $C$, Young $K$ and Negro F: A systematic review of hepatitis $C$ virus epidemiology in Asia, Australia and Egypt. Liver Int 2011, 31 Suppl 2:6180. | Article | PubMed

19. Prabdial-Sing N, Puren AJ, Mahlangu J, Barrow $P$ and Bowyer SM: Hepatitis $C$ virus genotypes in two different patient cohorts in Johannesburg, South Africa. Arch Virol 2008, 153:2049-58. | Article | PubMed

20. Pham VH, Nguyen HD, Ho PT, Banh DV, Pham HL, Pham PH, Lu L and $A b e \mathrm{~K}$ : Very high prevalence of hepatitis $\mathrm{C}$ virus genotype 6 
Daw et al. Virology Discovery 2013,

variants in southern Vietnam: large-scale survey based on sequence determination. Jpn J Infect Dis 2011, 64:537-9. | PubMed

21. Teoh NC, Farrell GC and Chan HL: Individualisation of antiviral therapy for chronic hepatitis C. J Gastroenterol Hepatol 2010, 25:1206-16. | Article I PubMed

22. The World Medical Association Ethics Unit. Declaration of Helsinki. [7 Jun 2009]. I Website

23. Thomas DL and Seeff LB: Natural history of hepatitis C. Clin Liver Dis 2005, 9:383-98. | Article | PubMed

24. Jimenez-Luevano MA, Lerma-Diaz JM, Hernandez-Flores G, JimenezPartida MA and Bravo-Cuellar A: Addition of pentoxifylline to pegylated interferon-alpha-2a and ribavirin improves sustained virological response to chronic hepatitis $\mathrm{C}$ virus: a randomized clinical trial $A n n$ Hepatol 2013, 12:248-55. | Article | PubMed

25. Inoue Y, Hiramatsu N, Oze T, Yakushijin T, Mochizuki K, Hagiwara H, Oshita $M$, Mita $E$, Fukui $H$, Inada $M$, Tamura $S$, Yoshihara $H$, Hayashi $E$, Inoue A, Imai Y, Kato M, Miyagi T, Hohsui A, Ishida H, Kiso S, Kanto T, Kasahara A, Takehara $T$ and Hayashi N: Factors affecting efficacy in patients with genotype $\mathbf{2}$ chronic hepatitis $\mathrm{C}$ treated by pegylated interferon alpha- $\mathbf{2 b}$ and ribavirin: reducing drug doses has no impact on rapid and sustained virological responses. J Viral Hepat 2010, 17:336-44| Article | PubMed

26. Baker DE: Pegylated interferon plus ribavirin for the treatment of chronic hepatitis C. Rev Gastroenterol Disord 2003, 3:93-109. I PubMed

27. Kogure T, Ueno Y, Fukushima K, Nagasaki F, Kondo Y, Inoue J, Matsuda Y, Kakazu E, Yamamoto T, Onodera H, Miyazaki Y, Okamoto H, Akahane T, Kobayashi T, Mano Y, Iwasaki T, Ishii M and Shimosegawa T: Pegylated interferon plus ribavirin for genotype Ib chronic hepatitis $\mathrm{C}$ in Japan. World J Gastroenterol 2008, 14:7225-4230 | Article | PubMed Abstract | PubMed FullText

28. Yu JW, Sun LJ, Kang P, Yan BZ and Zhao YH: Efficacy and factors influencing treatment with peginterferon alpha-2a and ribavirin in elderly patients with chronic hepatitis C. Hepatobiliary Pancreat Dis Int 2012, 11:185-92. | Article | PubMed

29. Xie Y, Xu DZ, Lu ZM, Luo KX, Jia JD, Wang YM, Zhao GZ, Zhang SL and Zhang DZ: Predictive factors for sustained response to interferon treatment in patients with chronic hepatitis C: a randomized, open, and multi-center controlled trial. Hepatobiliary Pancreat Dis Int 2005, 4:2139. | PubMed

30. Yu JW, Sun LJ, Zhao YH, Kang P and Yan BZ: Impact of sex on virologic response rates in genotype 1 chronic hepatitis $C$ patients with peginterferon alpha-2a and ribavirin treatment. Int J Infect Dis 2011, 15:e740-6. | Article | PubMed

31. Kainuma M, Furusyo N, Kajiwara E, Takahashi K, Nomura H, Tanabe Y, Satoh T, Maruyama T, Nakamuta M, Kotoh K, Azuma K, Shimono J, Shimoda $S$ and Hayashi J: Pegylated interferon alpha-2b plus ribavirin for older patients with chronic hepatitis C. World J Gastroenterol 2010, 16:4400-9. | Article | PubMed Abstract | PubMed FullText

32. Idrees $M$ and Riazuddin S: A study of best positive predictors for sustained virologic response to interferon alpha plus ribavirin therapy in naive chronic hepatitis C patients. BMC Gastroenterol 2009, 9:5. I Article | PubMed Abstract | PubMed FullText

33. Mangia A, Santoro R, Minerva N, Ricci GL, Carretta V, Persico M, Vinelli F, Scotto G, Bacca D, Annese M, Romano M, Zechini F, Sogari F, Spirito F and Andriulli A: Peginterferon alfa-2b and ribavirin for 12 vs. 24 weeks in HCV genotype 2 or 3. N Engl J Med 2005, 352:2609-17. | Article | PubMed

34. Elasifer HA, Agnnyia YM, Al-Alagi BA and Daw MA: Epidemiological manifestations of hepatitis $C$ virus genotypes and its association with potential risk factors among Libyan patients. Virol J 2010, 7:317. I Article | PubMed Abstract | PubMed FullText

35. Zeuzem S, Berg T, Moeller B, Hinrichsen H, Mauss S, Wedemeyer H, Sarrazin C, Hueppe D, Zehnter E and Manns MP: Expert opinion on the treatment of patients with chronic hepatitis C. J Viral Hepat 2009, 16:75-90. | Article | PubMed Abstract | PubMed FullText

36. Zeuzem S: Heterogeneous virologic response rates to interferon-based therapy in patients with chronic hepatitis $\mathrm{C}$ : who responds less well? Ann Intern Med 2004, 140:370-81. | Article | PubMed
37. Hartwell D and Shepherd J: Pegylated and non-pegylated interferon-alfa and ribavirin for the treatment of mild chronic hepatitis C: a systematic review and meta-analysis. Int J Technol Assess Health Care 2009, 25:5662. I Article I PubMed

38. Njouom R, Sartre MT, Timba I, Nerrienet E, Tchendjou P, Pasquier C and Rousset D: Efficacy and safety of peginterferon alpha-2a/ribavirin in treatment-naive Cameroonian patients with chronic hepatitis $\mathrm{C}$. J Med Virol 2008, 80:2079-85. | Article | PubMed

39. Snoeck E, Wade JR, Duff F, Lamb M and Jorga K: Predicting sustained virological response and anaemia in chronic hepatitis $C$ patients treated with peginterferon alfa-2a (40KD) plus ribavirin. Br J Clin Pharmacol 2006, 62:699-709. | Article | PubMed Abstract| PubMed FullText

40. Bzeizi KI: Hepatitis C treatment: trial by design. Saudi J Gastroenterol 2008, 14:51-2. | Article | PubMed Abstract | PubMed FullText

41. Siebert $U$ and Sroczynski G: Antiviral combination therapy with interferon/peginterferon plus ribavirin for patients with chronic hepatitis C in Germany: a health technology assessment commissioned by the German Agency for Health Technology Assessment. Ger Med Sci 2003, 1:Doc07 | Article | PubMed Abstract | PubMed FullText

\section{Citation:}

Daw MA, Elasifer HA, Dau AA and Agnan M. The role of hepatitis $\mathrm{C}$ virus genotyping in evaluating the efficacy of INF-based therapy used in treating hepatitis C infected patients in Libya. Virol Discov. 2013; 1:3. http://dx.doi.org/10.7243/2052-6202-1-3 